\title{
PENDIDIKAN BERKEMAJUAN: REFLEKSI PRAKSIS PENDIDIKAN K.H. AHMAD DAHLAN
}

\author{
Mohamad Ali, Sodiq A. Kuntoro, Sutrisno \\ FAI Universitas Muhammadiyah Surakarta, Universitas Negeri Yogyakarta, Universitas Islam \\ Negeri Yogyakarta \\ mohamadalisdmuhpk@ymail.com
}

\begin{abstract}
Abstrak
Artikel ini bertujuan untuk melacak: (1) fondasi, dimensi, dan filsafat dan teori pendidikan berkemajuan K.H. Ahmad Dahlan (1868-1923), dan (2) merefleksikan praksis pendidikan K.H. Ahad Dahlan untuk menyusun bagan konseptual pendidikan berkemajuan. Penelitian menggunakan metode sejarah yang mencakup empat tahapan: heuristik, kritik, interpretasi, dan historiografi. Mengaplikasikan analisis historis pendekatan situasional Berkhofer Jr. Penelitian berhasil menemukan bahwa: (1) fondasi pendidikan berkemajuan adalah agama yang berdialektika dengan kehidupan sosial; tiga dimensi pendidikan berkemajuan mencakup penghargaan atas akal (kecerdasan), berorientasi pada pengamalan (experience), dan menggerakkan kemajuan sosial (progress); filsafat dan teori pendidikan K.H. Ahmad Dahlan bercorak progresif religious yang mendorong kemajuan hidup duniawi dan kemuliaan hidup akhirat. (2) Secara konseptual pendidikan berkemajuan berlandaskan agama dan kehidupan sosial yang sangat menghargai kecerdasan (akal/inteligen) sebagai piranti untuk memahami pesan-pesan agama dan anatomi kehidupan sosial, dan bertujuan untuk menumbuhkan akal (kecerdasan) sehingga bertumbuh (growth) utuh kepribadiannya dan bersedia terlibat dalam menggerakkan kemajuan sosial (progress).
\end{abstract}

Kata kunci: K.H. Ahmad Dahlan, pendidikan progresif, pendidikan berkemajuan.

\section{PROGRESSIVE EDUCATION: EDUCATION PRAXIS REFLECTION OF K.H. AHMAD DAHLAN}

Mohamad Ali, Sodiq A. Kuntoro, Sutrisno

FAI Universitas Muhammadiyah Surakarta, Universitas Negeri Yogyakarta, Universitas Islam

Negeri Yogyakarta

mohamadalisdmuhpk@ymail.com

\begin{abstract}
This research is aimed at (1) investigating the foundation, dimension, and phylosophy of progressive education of K.H. Ahmad Dahlan (1868-1923), and (2) reflecting the education praxis of K.H. Ahmad Dahlan in the arrangement of conceptual design of progressive education. The research employed historical method including four steps: heuristic, criticism, interpretation, and historiography. Applying the situational-approach historical analysis proposed by Berkhofer Jr., the research reveals that: (1) the foundation of progressive education is religion which is dialectical with social life; three dimensions of progressive education include appreciation on mind (intelligence), orientation to implementation (experience), and the move of social advancement (progress); the educational phylosophy and theory of K.H. Ahmad Dahlan contains progressive religious pattern which encourages progress in secular life and glory in beyond. (2) Conceptually, progressive education stands on the basis of religion and social life with high appreciation in intelligence as a means to understand religious values and social life anatomy, and aims to grow reason (intelligence) for the betterment of a person's whole personality growth which makes him willing to be iinvolved in social progress.
\end{abstract}

Keywords: K.H. Ahmad Dahlan, progressive education 


\section{PENDAHULUAN}

Pengkaji sejarah pendidikan, Poerbakawatja (1968, pp. 212-220) menyebut tiga tokoh pendidikan pribumi sebagai perintis pendidikan moderen pada perguliran abad ke20. Dengan kecerdasan dan kegigihan, mereka meminjam senjata pamungkas (baca: sistem pendidikan) kolonial Belanda, namun sistem itu diolah dan diramu sedemikian rupa sehingga lebih cocok dengan kebutuhan penduduk pribumi. Ketiga tokoh pendidikan pribumi itu adalah K.H. Ahmad Dahlan (18681923) melalui pergerakan Muhammadiyah yang didirikan 18 November 1912, sepuluh tahun kemudian Ki Hadjar Dewantara (18891959) mendirikan Perguruan Taman Siswa pada tahun 1922, dan disusul Mohammad Sjafei (1893-1951) yang pada tahun 1926 mendirikan Ruang Pendidikan INS Kayutanam di Sumatra Barat.

Rintisan pendidikan modern yang didirikan ketiga tokoh pendidik pribumi ini dikenal dengan pendidikan kebangsaan (partikelir, rakyat, nasional) yang fungsinya untuk mencerdaskan bangsa dan mengobarkan semangat nasionalisme, serta sebagai institusi tandingan dan perlawanan terhadap pendidikan kolonial Belanda (Tsuchiya, 1986, pp. 188210). Dikatakan pendidikan kebangsaan karena orientasi dan tujuan pendidikannya untuk melahirkan manusia merdeka yang terbebas dari belenggu penjajah. Tujuan pendidikan ini berlawanan dengan pendidikan kolonial Belanda. Tujuan pendidikan kaum kolonial untuk melanggengkan kekuasaannya, atau sekedar mencukupi kebutuhan tenaga kerja untuk perkebunan, industri, dan memperkuat struktur kepegawaian kolonial.

Gagasan pendidikan ketiga perintis pendidikan modern ini perlu dikaji secara seksama. Namun dengan beberapa pertimbangan, studi ini memfokuskan perhatian pada satu tokoh saja, yaitu K.H. Ahmad Dahlan. Sedikitnya ada tiga alasan yang menjadi dasar pertimbangan mengapa tokoh ini yang dipilih menjadi subjek penelitian. Pertama, dari tiga tokoh perintis pendidikan nasional, hanya K.H. Ahmad Dahlan yang belum pernah menjadi Menteri Pendidikan dan Kebudayaan Republik Indonesia (Siswoyo, 2012, p. 157), sehingga tidak aneh bila kiprahnya cenderung terabaikan dalam perbincangan pergerakan nasional (Mulyana, 2008; Poesponegoro \& Notosusanto,1990)

Kedua, meski cenderung diabaikan dalam wacana pergerakan nasional, namun pada kenyataannya praksis pendidikan K.H. Ahmad Dahlan mampu menyebar ke seluruh pelosok Nusantara, dan hingga saat ini masih terus tumbuh baik secara kuantitatif maupun kualitatif. Laporan Pimpinan Pusat Muhammadiyah periode 2010-2015 menyebut bahwa jumlah Perguruan Tinggi Muhammadiyah adalah 177 buah, sedangkan jumlah sekolah/ madrasah/pesantren adalah 5.264 buah (PP Muhammadiyah, 2015, pp. 91-233). Menurut Fakhrudin (2015, p. 21) kunci suskes pendidikan Muhammadiyah berakar dari pandangan Kyai Dahlan yang menempatkan pendidikan sebagai wahana tajdid dan dakwah.

Alasan terakhir, K.H. Ahmad Dahlan bukan hanya mendirikan sekolah modern, karena pada saat bersamaan juga merintis pendidikan untuk orang dewasa dan kaum perempuan. Lebih dari itu, ia juga menaruh minat besar dalam pengembangan lembaga sosial yang lebih luas seperti kesehatan, panti asuhan, kepanduan, tabligh dan lain-lain. Melihat ruang gerak aktivitasnya yang begitu luas seolah-olah dia ingin menegaskan bahwa pendidikan itu seluas kehidupan. Berangkat dari pemahaman demikian, maka kegiatan pendidikan harus melibatkan peran bermacam-macam agent atau kelembagaan sebagaimana yang rintisnya itu.

Secara historis diakui bahwa pelopor pendidikan modern pribumi yang paling awal dan berpengaruh adalah Muhammadiyah (Noer, 1994, p. 84; Pringgodigdo, 1986, pp. 91-94). Makna penting kehadiran Muhammadiyah dalam kacamata pendidikan dan pergerakan kebangsaan dapat dilihat dari dua sudut pandang. Di satu sisi, pergulatan pendidikan pada masa pergerakan kebangsaan menjadi memiliki basis luas dan berakar kuat dalam masyarakat pribumi. Di sebelah lain, semangat dan nilai-nilai keagamaan (Islam) ikut mewarnai dan menjadi basis pergerakan kebangsaan (Kuntoro, 2006, p.136). Perluasan basis gerakan kebangsaan ini sangat strategis. Sebab, bagi penduduk pribumi yang mayoritas beragama Islam, Islam bukan hanya ikatan biasa, tapi benar-benar ikatan kelompok untuk melawan penjajah yang berbeda agama (Kahin, 1995, p. 50). 
Sekalipun bersaham besar dalam meletakkan dasar-dasar pendidikan modern, akan tetapi perhatian peneliti terhadapanya relatif kecil. Maarif (1996, p. 98), ketua umum Pimpinan Pusat Muhammadiyah periode 1998-2005 menandaskan: "Amat sedikit yang telah ditulis orang tentang kyai modernis ini, sekalipun pemerintah Indonesia telah mengangkatnya sebagai salah seorang pahlawan nasional". Minimnya perhatian terhadap K.H. Ahmad Dahlan membuat pemikiran besar dan amalannya yang fenomenal belum tergali secara optimal.

Maarif (1996, p. 69) menekankan bahwa tindakan Kyai Dahlan setelah berpikir mendalam, dan suatu pemikiran mendalam harus berujung pada tindakan. Hal ini menegaskan bahwa bagi Kyai Dahlan berpikir dan bertindak adalah satu rangkaian. Minimnya tulisan yang ditinggalkan, tapi pada saat bersamaan meninggalkan jejak karya nyata berlimpah membuat sebagian peneliti menilai bahwa K.H. Ahmad Dahlan seorang pragmatis. Islamolog asal Belanda, Steenbrink (1994, p. 52) menandaskan bahwa: "Dia bukan seorang teoritikus dalam bidang agama. Dia lebih bersifat pragmatikus yang sering menekankan semboyan pada murid-muridnya: sedikit bicara banyak bekerja". Penilaian bahwa Kyai Dahlan sebagai seorang pragmatis juga dikemukakan pengkaji sejarah awal Muhammadiyah, Alfian (1989, p. 150) yang menyatakan:

As a pragmatist he was bound not to have systematic ideas or teachings, therefore, if one were to try to find out what could be said about his systematic ideas and teachings one would be very disappointed, because Dahlan had so such thing. The only thing Dahlan had left us was this "pragmatism". And it is this pragmatism which was truely characteristic of Dahlan's Islamic modernism.

Penilaian atas K.H. Ahmad Dahlan sebagai seorang pragmatis penting digarisbawahi, karena dapat menjadi titik tolak dan pintu masuk untuk menggali pemikiran dan praksis pendidikannya. Apakah pemikiran dan praksis pendidikan K.H. Ahmad Dahlan senafas dengan penilaian Alfian dan Steenbrink? Seperti diketahui, dalam tradisi keilmuan Barat-Amerika, filsafat pragmatis melahirkan teori pendidikan progresif, sebagaimana ditampilkan John Dewey.

Kecenderungan umum studi tentang pemikiran pendidikan K.H. Ahmad Dahlan memfokuskan pada dua sudut pandang. Pertama, dari sudut pandang sejarah pendidikan pribumi nasional yang menekankan pada kontinuitas dan perkembangan pendidikan yang bermula dari pondok pesantren. Kedua, sudut pandang transnasional yang menempatkan praksis pendidikan Kyai Dahlan sebagai bagian dari mata rantai pembaharuan pemikiran Islam yang disuarakan Muhammad Abduh di Mesir (Wirjosukarto, 1962; Steenbrink, 1994; Tafsir, 1987; Arifin, 1987; Noer, 1994; Lubis, 1993).

Berbeda dengan kecenderungan di atas, studi ini berupaya menggali pemikiran pendidikannya dari sudut pandang pemikiran (teori) pendidikan modern. Permasalahannya adalah, teori pendidikan modern mana yang tepat dijadikan kerangka referensi? Untuk mengetahui hal itu, tinjauan sekilas terhadap pandangan sejumlah pakar atas praksis pendidikan K.H. Ahmad Dahlan perlu dilakukan. Fadjar (2010, p. 68) menekankan bahwa paradigma pendidikan Muhammadiyah adalah paradigma pembaharuan (tajdid). Senada dengan pandangan Fadjar, Abdulgani (1963, p. 39; 2013, p. 113) menilai bahwa bidang utama Muhammadiyah adalah "sosial-paedagogis", atau pedagogi sosial untuk melawan formalisme dan konservatisme Islam. Ia menambahkan, kekhususan K.H. Ahmad Dahlan ialah mendasarkan gerak hati untuk progress itu pada dasar moral yang kokoh dan indah, yaitu Islam murni dan modern. Poerbakawatja (1970, p. 217) mencatat bahwa dasar dan tujuan pendidikan K.H. Ahmad Dahlan ialah sosial, educative-religious, dan nasional.

Umnijah A. Wardi, murid K.H. Ahmad Dahlan, menandaskan bahwa pesan K.H. Ahmad Dahlan kepada murid-muridnya adalah: "dadijo kjai sing kemadjuan lan adja kesel-kesel anggonmu njambutgawe kanggo Muhammadiyah" (Wirjosukarto, 1962, p. 90). Dalam bahasa Indonesia kurang lebih berarti, menjadilah kyai yang mampu mengikuti perkembangan zaman dan tanpa lelah bekerja untuk Muhammadiyah. Maksud bekerja untuk Muhammadiyah adalah bekerja dan berjuang untuk memajukan dan menyejahterakan masyarakat. Makna kyai yang berkemajuan adalah seorang ulama yang dapat mengantisipasi Volume 4, Nomor 1, Juni 2016 
perkembangan zaman, mampu menerjemahkan dan mengamalkan pesan-pesan agama sesuai dengan konteks zamannya. Karena zaman modern ditandai perkembangan ilmu dan teknologi, maka agamawan harus mampu memahami dan memfungsikan ilmu dan teknologi untuk memahami pesan-pesan agama.

Bertitik tolak dari penilaian para pakar di atas, dapat diidentifikasi lima konsep kunci untuk memahami pemikiran dan praksis pendidikan K.H. Ahmad Dahlan, yaitu: pragmatis, progresif, sosial-paedagogis, pembaharuan (tajdid), dan berkemajuan. Kelima konsep itu tidaklah saling bertentangan, tetapi saling menopang dan menguatkan antar satu konsep dengan konsep lainnya. Dari lima konsep itu, peneliti cenderung memilih istilah berkemajuan untuk mencandra dan menamai gagasan pendidikan K.H. Ahmad Dahlan, secara singkat disebut dengan nama pendidikan berkemajuan. Ini artinya pendidikan berkemajuan itu menggunakan basis nilai-nilai agama (Islam) untuk mencapai kemajuan dalam kehidupan yang diarahkan bagi individu dan sosial yang terus menerus (berkelanjutan) berusaha aktif melakukan perbaikan kehidupan.

Secara hipotetik lima konsep kunci yang menjadi keunikan pendidikan berkemajuan bila disandingkan dengan dan dilihat dari perspektif teori-teori pendidikan modern lebih mendekati teori pendidikan progresif yang diperkenalkan John Dewey (1859-1952) di Amerika Serikat. Ornstein \& Levin (1985, pp. 238-241) menyebut gagasan pendidikan John Dewey sebagai pendidikan/pembelajaran melalui pengalaman/aktivitas (learning throught experience/activity). Dewey menentang suatu konsep belajar statis dan persekolahan tradisional yang menekankan pemberian pengetahuan teoritis-abstrak yang terpisah dari kehidupan. Apabila pengetahuan (teori) diperoleh melalui pengalaman, maka kebenaran suatu pengetahuan terletak pada makna pengalamannya untuk memecahkan masalah kehidupan. Teori dibuktikan oleh kebermaknaan dalam aktivitas pemecahan masalah, maka begitu juga pengetahuan yang diperoleh dari agama kebermaknaannya apabila diamalkan bagi pemecahan masalah kehidupan untuk mencapai kemajuan, sebagaimana K.H. Ahmad Dahlan mengkonsepsikannya.

Knight (1982, pp. 79-80) menandaskan bahwa teori pendidikan progresif berakar pada filsafat (pendidikan) pragmatis. Sebagaimana disinggung sebelumnya, Alfian dan Steenbrink menyebut K.H. Ahmad Dahlan juga sebagai seorang pragmatis. Meski terdapat titik-titik kesejajaran, harus hati-hati untuk menarik kesimpulan bahwa pendidikan berkemajuan sama dengan pendidikan progresif Dewey. Sebab, fondasi pemikiran keduanya berlainan. Fondasi pendidikan Dewey (2001, p. 332) bertolak dari filsafat kehidupan sosial empirik, sedangkan K.H. Ahmad Dahlan berlandaskan agama (Hadjid, 2008). Atau lebih jelasnya agama yang diamalkan dalam pemecahan masalah kehidupan, sebagaimana K.H. Ahmad Dahlan mengajarkan pada murid-muridnya tentang kandungan surat Al-Ma'un.

Tujuan penelitian ini untuk: (1) melacak fondasi pendidikan berkemajuan; (2) mengkaji dimensi pendidikan berkemajuan; (3) mengkaji filsafat dan teori pendidikan K.H. Ahmad Dahlan; dan (4) merekonstruksi pemikiran pendidikan berkemajuan.

Penelitian ini diharapkan dapat bermanfaat untuk: (1) memperkaya filsafat pendidikan dan teori-teori pendidikan, terutama dalam upaya pengembangan teori dan filsafat pendidikan yang berakar pada dinamika intelektual dan budaya Indonesia; (2) masukan bagi Kementerian Pendidikan agar dalam mengambil kebijakan pendidikan senantiasa mempertimbangkan khasanah pemikiran dan praksis pendidikan yang berakar pada agama dan budaya Indonesia sebagai salah satu dasar pertimbangan; (3) menginspirasi pelaku pendidikan untuk terus mengembangkan pemikiran dan eksperimen baru; (4) menyegarkan kembali ingatan pegiat pendidikan Muhammadiyah akan akar pendidikan yang dirintis K.H. Ahmad Dahlan; dan (5) memperjelas permasalahan pendidikan di Indonesia saat sekarang ini, lebih khusus lagi permasalahan pendidikan Muhammadiyah. Karena sejatinya peristiwa terdahulu menjadi causa efficient bagi peristiwa yang terjadi sesudahnya.

\section{METODE PENELITIAN}

Jenis penelitian ini adalah penelitian historis (sejarah) yang menggunakan metode sejarah untuk mencari, menguji dan menganalisa secara kritis rekaman dan peninggalan masa lampau dan usaha mensintesakan data menjadi penyajian dan kisah sejarah yang 
terpercaya (Gottschalk, 2008, p. 39; Barnadib, 1982 , p. 38). Seperti disinggung di atas, penelitian ini berupaya mengkaji praksis pendidikan K.H. Ahmad Dahlan. Azra (1999, p. 227) menandaskan bahwa kajian sejarah pendidikan (diskursus intelektual) termasuk wilayah kajian sejarah sosial. Sedangkan sejarah sosial mempunyai bahan garapan yang sangat luas dan beraneka ragam (Kuntowijoyo, 2003 , p. 39), proses penyajiannya dapat menggunakan dua model, sinkronis dan diakronis. Penelitian ini mengutamakan model sinkronis yang lebih mengutamakan lukisan yang meluas dalam ruang dengan tidak memikirkan terlalu banyak mengenai dimensi waktunya.

Instrumen utama penelitian adalah peneliti sendiri yang aktif mencari data-data sejarah tentang jejak dan pemikiran pendidikan K.H. Ahmad Dahlan, menyeleksinya, menggolong-golongkan, dan menginterpretasikan data-data tersebut. Perlu ditandaskan bahwa metode penelitian yang digunakan dalam penelitian ini adalah metode penelitian sejarah model penelitian historis faktual mengenai tokoh (Baker \& Zubair, 1990, p. 61) pendidikan bernama K.H. Ahmad Dahlan. Oleh karena itu, data-data yang dicari dan kumpulkan berkaitan data-data historis, atau sumber-sumber sejarah tentang tokoh pendidikan tersebut.

Untuk menganalisis data yang telah berhasil dikumpulkan, digunakan analisis sejarah pendekatan situasional, atau action frame of reference yang diperkenalkan Robert F. Berkhofer, Jr. Adapun unit analisisnya adalah situasi yang mengkombinasikan organisme manusia dengan lingkungannya dalam skema analitik yang tidak dapat dianggap terpisah (Alfian, 1992, p. 416). Sedikitnya ada empat faktor yang harus dianalisis oleh peneliti, yaitu: situasi pelaku, interpretasi pelaku terhadap situasi yang ada di lingkungannya, tindakan-tindakan yang dilakukan pelaku sebagai tanggapan atau reaksi atas lingkungannya, dan hasil atau akibat dari tindakannya baik yang diinginkan maupun yang tidak diinginkannya yang pada urutannya menjadi umpan balik (feedback) bagi pelaku untuk mendefinisikan dan menginterpretasikan kembali situasi lingkungan yang baru.

Dalam analisis sejarah, langkahlangkah yang dikemukakan di atas barulah tugas pertama, yaitu menjelaskan bagaimana pelaku memberi interpretasi terhadap situasi yang dihadapinya dan bagaimana aksi atau tindakan yang diambil untuk mengatasi situasi yang demikian. Pembahasan atas ketiga langkah tersebut peneliti kemukakan pada deskripsi data. Tugas kedua dalam analisis sejarah adalah mengemukakan pandangan peneliti terhadap pelaku sejarah, pemikiran, dan tindakannya setelah mencermati seluruh dinamika situasi (Alfian, 1992, p. 417).

\section{HASIL PENELITIAN DAN PEMBAHASAN}

Berdasarkan alur uraian di atas, untuk merekonstruksi pendidikan berkemajuan secara utuh, alur pembahasan bagian ini ditata menjadi empat bagian. Bagian pertama, melacak fondasi pendidikan berkemajuan sampai ditemukan bahwa agama berkemajuan dan kehidupan sosial adalah fondasinya; kedua, menelusuri kunci-kunci pemikiran pendidikan K.H. Ahmad Dahlan yang bermuara pada temuan tiga dimensi pendidikan berkemajuan; ketiga, mengkonstruksi filsafat pendidikan dan teori pendidikan berkemajuan; dan keempat, merefleksikan praksis pendidikan K.H. Ahmad Dahlan sehingga bisa ditampilkan dan direkonstruksi pemikiran pendidikan berkemajuan.

\section{Fondasi Pendidikan Berkemajuan}

Berdasarkan pelacakan konteks sosial-historis, dapat disimpulkan bahwa fondasi pendidikan berkemajuan adalah agama, lebih tepatnya agama yang berkemajuan. Hal ini berbeda dengan pemikiran pendidikan progresif John Dewey yang berlandaskan pada filsafat, lebih tepatnya filsafat pragmatis. Sekalipun secara umum fondasi pendidikannya berlainan; agama di satu sisi dan filsafat di sisi yang lain, tetapi ada titik kesepadanan yang menghubungkannya. Titik kesepadanan yang dimaksud adalah kata sifat yang menerangkan atau menyifatinya: agama berkemajuan, dan filsafat pragmatisme. Agama berkemajuan berpandangan bahwa agama harus menggembirakan bagi pemeluknya, dan menginspirasinya untuk bertindak dan terlibat dalam memecahkan masalah kehidupan, sehingga mampu mendorong kemajuan sosial. Hal itu senada dengan pemikiran filsafat pragmatis yang melihat kegunaan filsafat dari dampak yang ditimbulkan dalam memajukan kehiVolume 4, Nomor 1, Juni 2016 
dupan. Dengan demikian titik kesepadanannya terletak pada pragmatisme, yaitu agama maupun filsafat yang membumi, yang diterapkan dalam kehidupan sosial.

Sebagaimana disinggung di atas, baik agama berkemajuan maupun filsafat pragmatis, mencurahkan dan memberi perhatian besar pada kehidupan sosial sebagai orientasi dasar keagamaan di satu pihak, maupun orientasi filsafatnya. Hal ini menunjukkan bahwa kedua orientasi pemikiran pendidikan tersebut menyadari bahwa proses pendidikan berlangsung dalam suatu ruang sosial, pengalaman kehidupun, yaitu kehidupan sosial. Bertolak dari penjelasan tersebut dapat disimpulkan bahwa fondasi pendidikan berkemajuan Kyai Dahlan adalah agama dan kehidupan sosial.

\section{Tiga Dimensi Pendidikan Berkemajuan}

Rumusan pemikiran progresivisme pendidikan John Dewey yang paling representatif dan belakangan dirumuskan secara komprehensif termuat dalam bukunya, Experience and Education. Buku ini menjelaskan secara akurat sikap dan posisi pemikiran John Dewey di tengah dua arus pemikiran dan praktik pendidikan yang menonjol di Amerika Serikat pada paruh awal abad ke-20. Dari sini diketahui ciri khas progresivisme dihadapan arus pendidikan tradisional dan pendidikan romantis. Setelah mencermati gagasan Dewey di buku tersebut, sedikitnya ada tiga istilah kunci yang menonjol. Tiga istilah kunci yang dimaksud adalah konsep "experience", "intelligence", dan "progress". Bila tiga dimensi pendidikan berkemajuan K.H. Ahmad Dahlan disandingkan dengan tiga konsep kunci progresivisme pendidikan John Dewey terlihat demikian jelas titik-titik kesepadanannya sebagaimana nampak pada Tabel 1 .

Tabel 1. Konsep Kunci Pendidikan Ahmad Dahlan dan Dewey

\begin{tabular}{cll}
\hline No & K.H. Ahmad Dahlan & John Dewey \\
\hline 1 & Akal & Intelligence \\
2 & Pengamalan & Experience \\
3 & Berkemajuan & Pogress \\
\hline
\end{tabular}

Sumber: Diolah dari berbagi sumber

Menurut Dewey, tujuan pendidikan adalah untuk melakukan rekonstruksi atau reorganisasi pengalaman secara terus-mene- rus. Pendidikan berangkat dari pengalaman, oleh pengalaman, dan untuk pengalaman. Secara ontologis, kenyataan adalah interaksi antara individu dengan lingkungan (baca: pengalaman). Dari sudut epistemologi, pengetahuan merupakan produk dari pengalaman yang menggunakan metode saintifik. Sebagai penulis produktif, untuk menjelaskan idenya itu Dewey menulis sejumlah buku, antara lain: Democracy and Education dan Experience and Education.

Senafas dengan Dewey, Dahlan juga memandang bahwa pengamalan (amal saleh) sangat penting dalam proses pendidikan. Hal ini dapat kita simak dari pesan dan kata-kata hikmah yang berulangkali di sampaikan kepada murid-muridnya berikut ini: "sedikit bicara, tapi perbanyaklah bekerja"; "siapa menanam, akan mengetam"; hidup-hidupilah $\mathrm{Mu}$ hammadiyah, jangan mencari penghidupan di Muhammadiyah". Pesan-pesan demikian menegaskan bahwa Kyai Dahlan memandang perbuatan/amal saleh itu sangat penting. Sebab dengan berbuat/beramal saleh seseorang akan mendapatkan pengalaman baru, pengalaman itu akan digunakan untuk meningkatkan kualitas perbuatan/pengalaman berikutnya sehingga menjadi lebih realistik.

Pesan "sedikit bicara, tapi perbanyaklah bekerja" mengandung arti bahwa ajaran agama, ataupun teori-teori ilmu pengetahuan modern tidak akan pernah bermakna bagi kehidupan kalau hanya diceramahkan dan didiskusikan terus-menerus. Kata-kata, atau perbincangan di tingkat wacana tanpa dibarengi dengan tindakan dan aksi sosial hanya melahirkan verbalisme, omong kosong. Hal itu juga berlaku sebaliknya, tindakan tanpa disertai refleksi melahirkan aktivisme, atau manusia tukang. Hanya saja, menurut analisis sosial Kyai Dahlan, pemimpin umat pada saat itu banyak yang terperangkap pada verbalisme. Ajaran agama diceramahkan dan dibicarakan, tetapi tidak bersedia untuk mengamalkan. Menurutnya, ada tiga kelemahan mendasar pemimpin: (1) terbatasnya ilmu pengetahuan; (2) lebih banyak omong tinimbang aksi/ berbuat; dan (3) lebih mementingkan diri sendiri dan kelompoknya dari pada kepentingan umum (Dahlan,1923; Maarif, 2000, p. 31). Dengan membaca konteks sosial di mana kalimat itu dikemukakan, kita semakin bertambah paham betapa ajakan untuk lebih banyak bekerja dan beramal (bertindak) itu benar- 
benar menjadi gerakan perlawanan untuk menghadapi arus besar masyarakat yang lebih gemar ngomong dari pada bertindak.

K.H. Ahmad Dahlan tidak berhenti pada kata-kata, tapi menjelaskan dan mencontohkan secara kongkrit dengan perbuatan. Dalam novel Sang Pencerah, Basral, p. 337) pada episode "membahas kentut di Kweekschool" menjelaskan bagaimana cara mengajar K.H. Ahmad Dahlan lewat pengalaman aktual anak (suasana kelas), kemudian dielaborasi dengan metode saintifik, dan diakhiri dengan refleksi tentang kehidupan. Pembahasan masalah kentut bermula dari peristiwa yang sesungguhnya, kentut seorang siswa di kelas. Dari peristiwa itu kemudian menjadi pembuka pintu untuk memasuki materi pelajaran tentang pengenalan agama Islam. Namun sebelum itu, kentut dielaborasi dari sudut pandang ilmu biologi dan kesehatan manusia sehingga peserta didik diajak berpikir dan berdialog tentang agama (khalik-pencipta) melalui sudut pandang ilmu pengetahuan. Proses pembelajaran melalui pengalaman dan permasalahan aktual yang dialami anak, kemudian dilihat dari sudut keilmuan dan diakhiri dengan refleksi keagamaan yang ternyata sangat mengesankan dan menarik minat anak-anak untuk terus belajar kepada Kyai Dahlan.

Contoh paling popular tentang pentingnya beramal/bertindak /pengamalan tercermin ketika mengajarkan surat Al-Maun. Kyai Dahlan memulai dengan penjelasan konsep-konsep kunci, kemudian surat dipahami dan dihafal di luar kepala oleh muridmuridnya. Sampai di sini dikira sudah rampung, namun dia menuntut dan mengajak murid-muridnya mengamalkan isi surat itu dalam kehidupan dengan jalan membantu fakir miskin. Dalam pandangan Kyai Dahlan, memahami berarti mengamalkan apa yang telah diketahuinya itu dalam kehidupan sosial.

Beralih ke dimensi berkemajuan. Sebagaimana telah dibicarakan di muka, pesan K.H. Ahmad Dahlan yang berulangkali disampaikan kepada murid-muridnya, sebagaimana dituturkan salah satu muridnya bernama Umnijah ketika diwawancarai Wirjosukarto (1962, p. 90) adalah "dadijo kjai sing kemadjuan. Artinya, menjadilah kyai (ulamaintelektual) yang berkemajuan (progresif). Kyai ataupun intelektual berkemajuan adalah ilmuwan yang mampu menangkap tanda- tanda zaman, membaca ke arah mana arus perubahan bergerak, sehingga tidak berhenti di tempat. Ilmuwan berkemajuan mampu mengantisipasi perubahan yang akan terjadi berdasarkan pengalaman yang dilalui. Mengantisipasi perubahan berarti mampu berpikir projektif (visioner) dan bertindak secara antisipatif.

Dimensi berkemajuan sebagai orientasi pendidikan bukan hanya digerakkan kesadaran bahwa kehidupan sosial selalu berkembang, tetapi juga berlandaskan pada semangat ajaran agama. Kuntowijoyo (1998, p. xvii), sejarawan UGM yang aktivis $\mathrm{Mu}$ hammadiyah, mengutip Suwara Muhammadiyah tahun I (1915) Nomor 2, p. 29, ditulis: "awit miturut paugeraning agami kita Islam, serta cocok kaliyan pikajenganipun jaman kemajengan". (Sebab menurut tuntunan agama kita Islam, serta sesuai dengan kemauan zaman berkemajuan). Kutipan tersebut menegaskan bahwa dimensi berkemajuan dalam pendidikan juga merupakan tuntunan, atau sesuai dengan ajaran agama Islam. Ajaran Islam yang dipahami dengan akal suci dan ilmu mantik mendorong semangat untuk berijtihad, bekerja keras untuk mengeluarkan hukum-hukum agama. Dengan jalan demikian, maka agama Islam bisa fungsional dalam memecahkan problematika kehidupan.

Dimensi terakhir dari tiga dimensi pendidikan berkemajuan K.H. Ahmad Dahlan adalah dimensi akal. Dalam pandangannya, watak akal adalah menerima hal-hal yang suci dan bersih berupa ilmu pengetahuan. Untuk lebih gamblangnya berikut kami cuplikan konsep akal menurut penuturan Dahlan (1923):

Watak akal itu menerima segala pengetahuan dan memang pengetahuan itulah yang menjadi kebutuhan akal, sebab akal itu seperti biji yang terbenam di dalam bumi. Agar biji itu dapat tumbuh menjadi pohon yang besar, tentu perlu disirami secara ajek dan dipenuhi kebutuhan lainnya. Demikian juga akal manusia, niscaya tidak dapat bertambah sampai kepada kesempurnaannya, apabila tidak diberi siraman dengan pengetahuan. Dan semuanya itu mesti sesuai dengan kehendak Tuhan Yang Kuasa.

Sungguh menarik penjelasan analogis tersebut. Akal dianalogikan dengan biji pohon Volume 4, Nomor 1, Juni 2016 
yang terbenam atau berada di dalam tanah. Supaya biji itu dapat tumbuh secara optimal dan diikuti dengan buah yang lebat dibutuhkan tangan manusia untuk menyiram dan merawatnya secara terus-menerus. Sebaliknya, apabila biji yang secara potensial dapat bertumbuh menjadi pohon yang lebat namun bila tidak dirawat bisa mengalami kegagalan. Atau, kalaupun bisa tumbuh menjadi pohon, pertumbuhannya tidak terjadi secara optimal. Mengilustrasikan akal dengan biji sangat tepat. Sebab, sebagaimana biji, akal pun akan mengalami keadaan yang sama bila tidak disirami dengan pengetahuan melalui proses pendidikan dan interaksi sosial. Pengetahuan yang digunakan untuk merawat akal itu harus sejalan dengan kehendak Allah Yang Maha Kuasa.

Dalam penjelasan selanjutnya, Dahlan melihat bahwa setinggi-tinggi pengetahuan untuk menyirami akal adalah ilmu mantik (ilmu tentang logika/cara berpikir yang benar). Dari uraian tentang dimensi akal, dapat ditarik garis kesepadanan dengan konsep intelligence, kecerdasan seperti yang dirumuskan John Dewey. Baik K.H. Ahmad Dahlan maupun John Dewey memahami akal atau kecerdasan sebagai pisau analisis untuk membedah dan memecahkan masalah-masalah kehidupan yang membelit manusia. Dengan demikian, keduanya memahami akal (intelligence) sebagai sebuah proses, sebagai kata kerja. Dimensi akal menjadi titik pembeda manusia dengan makhluk-makhluk yang lain. Dengan kemampuan akal inilah manusia menatap masa depan secara optimis, bahwa semua tantangan dan permasalahan dapat diurai dan dipecahkan.

\section{Filsafat Pendidikan dan Teori Pendidikan Berkemajuan}

Sebagaimana dijelaskan secara skematis pada tabel 2 di bawah, secara ontologis (metafisika), hakikat tentang sesuatu yang ada, terdapat perbedaan mendasar antara filsafat pendidikan K.H. Ahmad Dahlan dengan John Dewey. Meminjam istilah Knight (1982, p. 14), K.H. Ahmad Dahlan menganut pemahaman metafisika teologis (metafisika religius). "Sesungguhnya tidak ada yang lain dari maksud dan kehendak manusia itu ialah menuju kepada keselamatan dunia dan akhirat", tandas K.H. Ahmad Dahlan (1923). Dalam pemahaman Dahlan, Allah SWT adalah Pen- cipta (Sang Khalik) alam semesta dan seisinya, termasuk manusia. Sedangkan alam semesta dan manusia adalah hasil ciptaan Allah SWT (makhluk). Di sebelah lain, pengalaman manusia yang merupakan produk dari interaksi manusia dan alam (lingkungan), merupakan ontologi dalam filsafat pendidikan Dewey.

Konsep pengalaman manusia dalam pemahaman ontologi Dewey itu seluas konsep makhluk dalam pandangan K.H. Ahmad Dahlan. Pada titik ini, konsep pengalaman dalam pandangan John Dewey yang merupakan proses interaksi terus-menerus antara manusia dengan lingkungannya, memiliki area yang sama dengan konsep makhluk dalam pandangan K.H. Ahmad Dahlan. Manusia sebagai khalifah (wakil Allah SWT di muka bumi (alam/lingkungan) harus bergerak aktif untuk membangun kebaikan dan membaguskan kehidupan. Titik perbedaan terletak pada ketiadaan dimensi teologis, religiusitas, maupun konsep Tuhan sebagai Pencipta dalam pandangan ontologi John Dewey.

Berangkat dari konsep khalifah fil ard (wakil Allah di bumi), K.H. Ahmad Dahlan berpandangan bahwa manusia adalah pelaku aktif dalam menciptakan kehidupan yang baik di muka bumi. Kehidupan di dunia ini merupakan tantangan yang harus dijawab dengan jalan melibatkan diri dalam upaya membaguskan kehidupan. "Siapa yang menanam, akan mengetam", kata K.H. Ahmad Dahlan. Dunia ini adalah lahan dan ladang tempat untuk menanam kebaikan dan mengolah seluruh sumber daya yang ada di dalamnya untuk kemakmuran rakyat dan memajukan kehidupan. Panggilan iman untuk terlibat aktif dalam membaguskan dan memajukan kehidupan manusia di dunia ini merupakan jalan memperoleh kebahagiaan akhirat. Dengan kata lain, kehidupan agama berkemajuan dalam pandangan K.H. Ahmad Dahlan, bukanlah kehidupan religius yang membelakangi kehidupan duniawi, tetapi yang terjun langsung menggumuli dan memecahkan masalah-masalah kehidupan empirik (duniawi).

K.H. Ahmad Dahlan optimis bahwa manusia dapat mengemban tugas kekhalifahan, sebab manusia dibekali dengan akal yang digunakan untuk berpikir. Sementara itu, optimisme John Dewey atas manusia karena manusia memiliki intelligence (kecerdasan). Kapasitas berpikir, atau kecerdasan inilah yang menjadi modal utama manusia untuk 
memahami dan memecahkan permasalahan yang muncul, baik masalah-masalah personal, sosial, kebangsaan maupun global. Pendidikan bertugas untuk melatih akal dan mengasah kecerdasan, sehingga potensi akal tumbuh optimal. Optimalisasi pertumbuhan akal ditandai dengan kemampuan dan kesanggupannya dalam memecahkan problematika kehidupan.

Kapasitas berpikir, ataupun kecerdasan yang melekat pada diri setiap orang inilah yang memungkinkan manusia untuk menyelami dan memiliki kebebasan, K.H. Ahmad Dahlan memakai istilah "kamerdekan". Dengan kebebasan yang dimilikinya, manusia dapat memilih berbagai jalan kehidupan secara bertanggungjawab. Pengertian bertanggung jawab dalam pemahaman John Dewey lebih bermakna untuk kemajuan empirik duniawiyah, sedangkan dalam pandangan K.H. Ahmad Dahlan pertanggungjawaban manusia itu meliputi kemajuan empirik duniawi sekaligus keselamatan dan kemuliaan hidup ukhrowi (metafisik/transendental).

Namun demikian, pemahaman K.H. Ahmad Dahlan atas wahyu tidak berhenti pada konsep normatif-tekstual, tapi menelisik masuk ke dalam ranah kontekstual. Bahkan, tidak berhenti pada pemahaman kontekstual. Teks-teks normatif wahyu dijadikan kerangka dasar untuk aksi sosial (beramal shalih), dan K.H. Ahmad Dahlan sendiri adalah penerjemah dan pelaku utama atas perintah wahyu tersebut. Singkatnya, kebenaran normatif wahyu diterjemahakan dalam perilaku dan praksis sosial. Dengan cara demikian, kebenaran wahyu menjadi aktual dan fungsional sehingga benar-benar termanifestasi dalam kehidupan sosial.

Secara aksiologis, garis penghubung gagasan pendidikan berkemajuan K.H. Ahmad Dahlan dengan progresivisme pendidikan John Dewey terletak pada nilai kemanfaatan dalam kehidupan sebagai tolak ukur untuk menilai kebenaran suatu gagasan. Hanya saja, nilai kemanfaatan itu bagi K.H. Ahmad Dahlan bukan hanya semata-mata untuk kepentingan kebaikan dan kesejahteraan kehidupan di dunia ini, namun berimplikasi jauh hingga kehidupan akhirat (eskatologis). Sebab, K.H. Ahmad Dahlan meyakini bahwa ada kehidupan yang lebih kekal setelah kehidupan di dunia ini berakhir, yaitu kehidupan akhirat.

Postur filsafat pendidikan K.H. Ahmad Dahlan yang disandingkan dengan John Dewey secara mudah dan skematis dapat disimak pada Tabel 2. Secara ringkas dan padat dapat lihat titik-titik kesapadanan yang membingkainya enjadi suatu mazhab pendidikan progresif. Pada saat bersamaan juga tampak begitu jelas garis-garis persilangan seperti tergambar dalam kunci-kunci pemikiran kedua tokoh pendidikan ini apabila dilihat dari sudut pandang ontologi, epistemologi dan aksiologinya.

Tabel 2. Konstruksi Filsafat Pendidikan K.H. Ahmad Dahlan

\begin{tabular}{|c|c|c|c|}
\hline No. & Filsafat Pendidikan & K.H. Ahmad Dahlan & John Dewey \\
\hline & Ontologi & $\begin{array}{l}\text { Khalik (pencipta) dan Makhluk } \\
\text { (pengalaman empirik) }\end{array}$ & $\begin{array}{l}\text { Makhluk/Pengalaman empirik- } \\
\text { sekularistik. }\end{array}$ \\
\hline 2 & Epistemologi & $\begin{array}{l}\text { Sumber pengetahuan meliputi } \\
\text { wahyu, akal dan pengalaman. } \\
\text { Kebenaran adalah memfungsikan } \\
\text { ketiga sumber itu untuk } \\
\text { memecahkan masalah kehidupan } \\
\text { empiric duniawi dan mencapai } \\
\text { kebaikan akhirat. }\end{array}$ & $\begin{array}{l}\text { Pengetahuan olahan pengalaman } \\
\text { dengan metode keilmuan, } \\
\text { kebenaran adalah berfungsinya } \\
\text { pengetahuan dalam memecahkan } \\
\text { masalah kehidupan empirik } \\
\text { duniawai }\end{array}$ \\
\hline 3 & Aksiologi & $\begin{array}{l}\text { Nilai baik-buruk sebagian bersifat } \\
\text { relatif, wahyu bernilai mutlak, } \\
\text { tetapi pemahaman manusia atas } \\
\text { wahyu adalah relatif. }\end{array}$ & $\begin{array}{l}\text { Nilai baik-buruk dari pengalaman } \\
\text { empirik-sekularistik bersifat } \\
\text { situasional dan relatif. }\end{array}$ \\
\hline
\end{tabular}

Sumber: Dikembangkan dari Knight, 1982, pp. 12-34; Wirjosukarta, 1962, p. 67. 
Sejalan dengan konsep ontologis filsafat pendidikan K.H. Ahmad Dahlan yang bercorak empirik-religius, maka tujuan pendidikannya juga berhaluan empirik-religius. Meskipun selama hidupnya K.H. Ahmad Dahlan belum merumuskan secara eksplisit tujuan pendidikannya, namun Wirjosukarto (1962, p. 59) berdasarkan wawancara dengan murid-murid pendiri Muhammadiyah itu, menegaskan bahwa rumuskan tujuan pendidikannya adalah untuk melahirkan manusia religius yang seluruh potensi pribadi (individualitas) dapat tumbuh secara bulat (utuhoptimal), bermoral tinggi, dan memiliki sikap sosial positif yang termanifestasi dalam bentuk aksi sosial untuk memajukan kehidupan dan mensejahterakan masyarakat.

Tujuan pendidikan K.H. Ahmad Dahlan sebagaimana dirumuskan di atas, memiliki titik kesajajaran dengan rumusan tujuan pendidikan John Dewey. Titik temu keduanya pada istilah pertumbuhan. Baik Kyai Dahlan maupun Dewey menekankan pada pertumbuhan pribadi atau individu yang utuh. Hanya saja, dalam trisula tujuan pendidikan Dahlan sedikit berbeda dengan tujuan pendidikan Dewey. Trisula tujuan pendidikan Dahlan adalah pertumbuhan individu, moral, dan sosial, sedangkan trisula tujuan pendidikan Dewey meliputi pertumbuhan individu, sosial, dan intelektual. Dari situ terlihat seolah-olah Dewey lebih menekankan pada dimensi intelektual, sedangkan Dahlan lebih menekankan pada moral, atau akhlak. Cara pandang demikian tidak bisa dibenarkan. Gagasan K.H. Ahmad Dahlan tentang pendidikan akal, sebagaimana tertuang dalam tulisannya yang berjudul "tali pengikat hidup", menegaskan komitmennya atas pendidikan dan pertumbuhan akal sebagai instrument untuk memahami wahyu dan membedah realitas sosial secara dialektis.

Sebagaimana nampak pada pemahaman ontologi ataupun metafisika filsafat pendidikannya, titik persimpangan tujuan pendidikan Dahlan dan Dewey terjadi dalam melihat manusia. K.H. Ahmad Dahlan melihatnya sebagai manusia religius, sedangkan John Dewey adalah manusia sekular. Dewey menekankan dan mengutamakan kesejahteraan dan kemajuan kehidupan di dunia ini. Sedangkan K.H. Ahmad Dahlan meyakini adanya kehidupan setelah kehidupan dunia ini, kesadaran eskatologis. Oleh karena itu,
K.H. Ahmad Dahlan memandang kehidupan dunia ini sangat penting sebagai lahan bekerja keras untuk mewujudkan kesejahteraan umat manusia dan memajukan kehidupan sebagai manifestasi amal shaleh di mana amal shaleh itu akan mendapat balasan kehidupan yang baik di akhirat (pahala surga). Keyakinan eskatologis inilah yang menjadi titik persimpangan jalan antara tujuan pendidikan K.H. Ahmad Dahlan dan John Dewey.

Setelah sketsa tujuan pendidikan tergambar secara jelas, langkah berikut adalah menelusuri program pendidikan, atau kurikulumnya yang merupakan jalan untuk meraih tujuan atau cita-cita yang telah ditetapkan. Baik Kyai Dahlan maupun John Dewey menekankan penemuan-penemuan manusia yang paling maju sebagaimana termanifestasi dalam perkembangan ilmu pengetahuan dan teknologi modern sebagai muatan kurikulum pendidikan. Dalam hal ini tidak ada perbedaan mendasar antara kedua pemikir pendidikan ini. Hanya saja karena tujuan pendidikannya berlainan: menjadi manusia progresif-religius (ulama berkemajuan) di satu dan manusia progresif-sekular di sisi yang lain, maka kurikulumnya juga ada perbedaan. Kurikulum pendidikan menurut K.H. Ahmad Dahlan adalah ilmu pengetahuan dan teknologi modern plus agama Islam. Perlu ditekankan di sini bahwa pengajaran agama Islam dalam pandangan K.H. Ahmad Dahlan tidak secara doktriner, tapi disesuaikan dengan pengalaman kemajuan manusia (ilmu pengetahuan dan teknologi modern). Dengan demikian, pengajaran agama Islam dalam konsepsi kurikulum K.H. Ahmad Dahlan terintegrasi dan sebangun dengan ilmu pengetahuan dan teknologi modern.

Pada tahun 1924, tepat setahun setelah K.H. Ahmad Dahlan meninggal dunia, bagian sekolah mempublikasikan kurikulum (Leerplan) untuk Sekolah Muhammadiyah II (Angka Lara) mulai dari kelas 1 hingga kelas 6 (Suara Muhammadiyah No.4/1924). Sebagaimana terbaca dalam lampiran, di situ dijelaskan secara rinci dan mendetil bagaimana kurikulum sekolah Muhammadiyah untuk setiap kelas. Pada intinya untuk mata pelajaran umum sekolah Muhammadiyah mengikuti dan menyesuaikan diri dengan kebijakan pendidikan pemerintah kolonial Belanda (Hindia Belanda), namun dengan menambahkan mata pelajaran agama Islam. 
Sebagaimana dijelaskan di bab-bab terdahulu, Kyai Dahlan tidak membedakan secara diametral antara mata pelajaran umum dengan mata pelajaran agama. Sebab, pada hakikatnya sumber kebenaran hanya satu, yaitu Allah. Mata pelajaran agama Islam berisi pemahaman manusiawi dan rumusanrumusan doktrin atas wahyu (al-Quran) dan Sunnah Nabi Muhammad. Di sebelah lain, mata pelajaran umum merupakan ikhtiar manusia untuk memahami dan merumuskan ayat-ayat Allah SWT yang terbentang dalam bentuk alam semesta beserta seluruh isinya. Dengan demikian, baik mata pelajaran agama Islam maupun mata pelajaran umum pada hakikatnya berasal dari sumber yang sama, yaitu Allah SWT. Pemahaman yang demikian inilah yang membuat Kyai Dahlan sama sekali tidak canggung ketika meminjam temuantemuan kemajuan dan kemodernan yang pada saat itu identik dengan kaum penjajah Belanda. Perkakas kemoderenan yang dipinjamnya antara sistem persekolahan, ilmu pengetahuan dan teknologi modern, dan pembangunan rumah sakit.

K.H. Ahmad Dahlan memahami subjek didik atau murid sebagai pribadi yang aktif dalam mencari kebenaran dan memecahkan permasalahan kehidupan sosial umat Islam. Dia lebih banyak menghadapi muridmurid yang sudah dewasa, sehingga muridmuridnya diposisikan sebagai teman dialog dalam memecahkan masalah-masalah kehidupan yang dihadapi. Pandangan demikian, memposisikan murid sebagai teman dialog, sejalan dengan konsep agama sebagai fitrah yang dimiliki semua manusia. Manifestasi konsep fitrah dalam pendidikan adalah memahami anak (peserta didik) sebagai pribadi yang aktif untuk terlibat dalam proses pencarian kebenaran. Sebangun dengan konsep K.H. Ahmad Dahlan, John Dewey juga melihat anak (peserta didik) sebagai pribadi yang aktif untuk bergerak. Karena anak dipandang sebagai pribadi yang aktif, maka baik Dahlan maupun Dewey menyarankan agar anak dilibatkan secara aktif dalam proses pembelajaran.

Cara untuk mengaktifkan siwa adalah dengan mengajak siswa untuk memasuki permasalahan-permasalahan aktual kehidupan. Permasalahan aktual kehidupan ini menjadi tantangan dan eksperimen untuk mengasah kemampuan intelektual, dalam istilah
Dahlan meningkatkan kapasitas akal. Kemampuan akal ataupun kapasitas intelektual terasah dengan jalan latihan terus menerus untuk memahami dan memecahkan masalahmasalah aktual kehidupan. Kecerdasan seorang subjek didik tidak diukur dari kemampuan dalam menghafal teks-teks pelajaran, namun secara dinamis-dialektis terlihat dari kemampuannya dalam memecahkan masalah kehidupan yang membelit dirinya, masyarakatnya, dan problem kemanusiaan secara global.

John Dewey maupun K.H. Ahmad Dahlan mendambakan pendidik yang mampu mengoptimalkan pertumbuhan segenap potensi peserta didik. Pendidik yang ideal adalah pendidik berkemajuan atau progresif, yaitu pendidikan mampu menciptakan suasana dan lingkungan pembelajaran yang kondusif untuk tumbuh kembang warga belajar dan menstimulasi mekarnya segenap potensi subjek didik secara optimal. Pendidik berkemajuan adalah pendidik (guru) yang juga murid, di samping dia sebagai guru yang mengajar, dia juga berperan sebagai murid yang belajar dari pengalaman berkomunikasi dengan siswa. Pendidik terus-menerus belajar sepanjang hidup dan belajar dari proses sosial. Pada titik ini nampaknya tidak terdapat titik perbedaan antara Dewey dan Dahlan dalam memahami guru, atau pendidik yang ideal.

Namun bila ditelaah lebih dalam, sebetulnya ada satu titik perbedaan. K.H. Ahmad Dahlan mengidealkan pendidik yang bukan saja mampu menciptakan lingkungan dan situasi pembelajaran yang kondusif, namun juga meniscayakan pendidik yang mampu menjadi tauladan dalam bertindak kebaikan. Keteladanan pendidik (guru) mendapat penekanan sebagaimana ditandaskan dalam "Ketentuan Sekolah Muhammadiyah" yang dikeluarkan oleh Muhammadiyah Bagian Sekolahan pada tahun 1924 (Terlampir) menyatakan: "Dalam hal tertib, kebersihan dan lakoe kebajikan, semoea goeroe haroes beroesaha akan menjadi tjontoh kepada moerid-moerid dan orang sekampoengnya”.

Pembahasan tentang pendidik ideal di atas telah sedikit menyiratkan metode pembelajarannya. Metode pembelajaran yang paling baik untuk menciptakan suasana belajar yang kondusif adalah metode pemecahan masalah (problem solving). John Dewey secara jelas merumuskan metode belajarnya 
dengan sebutan pendekatan saintifik/keilmuan yang dimulai dengan identifikasi masalah, merumuskan hipotesis, dan mengumpulkan data, dan terakhir menguji hipotesis (Akinpelu,1988: 145). Sebagai implementasi pendekatan saintifik lalu dikembangkan metode projek, di mana tema-tema pembelajaran dikembangkan menjadi seperangkat aktivitas yang perlu dilakukan siswa. Dengan melakukan aktivitas tersebut, peserta didik mengalami dan menghayati permasalahan dan proses pemecahan masalah secara langsung.

Untuk lebih memudahkan memahami postur teori pendidikan berkemajuan, sebagaimana diuraikan di atas, secara ringkas dan padat disajikan Tabel 3.

Dari tampilan Tabel 3 dapat dilihat lebih jelas bagaimana titik-titik kesepadanan pemikiran pendidikan yang membingkai kedua tokoh pendidikan ini. Oleh karena itu, tidak berlebihan dan sudah pada tempatnya apabila digolongkan dan ditempatkan dalam satu mazhab, yaitu progresivisme pendidikan atau pendidikan progresif. Namun demikian, pada saat bersamaan juga dapat dicermati garis persimpangan yang membelah keduanya kepada dua percabangan progresivisme pendidikan, yaitu pendidikan progresif religius dan pendidikan progresif sekular. Diskusi dan upaya penajaman atas konsepsi atau pemikiran pendidikan progresif religius akan dikaji lebih lanjut pada bagian refleksi di bawah ini.

\section{Refleksi}

Problem akademis yang coba dijawab oleh penelitian ini adalah bagaimana implikasi dan formulasi pragmatisme K.H. Ahmad Dahlan dalam pendidikan yang dikembangkannya. Tesis yang dikemukakan sejumlah pakar, sebagaimana banyak dibicarakan di muka, menyatakan bahwa Kyai Dahlan adalah seorang pragmatis, pragmatikus, manusia amal, berorientasi pada praksis sosial, dan lebih mengutamakan bertindak ketimbang merumuskan gagasan secara literer, nampaknya sulit dibantah. Namun demikian, harus segera ditambahkan bahwa pernyataan itu bukan berarti bahwa ketika bertindak dan beramal saleh Kyai Dahlan tidak memikirkannya secara mendalam dan mendasar. Tindakan dan praksis sosial yang dilakukannya justru merupakan manifestasi, atau perwujudan dari pemikiran baru (tajdid) yang dipikirkannya secara mendalam. Karena dalam pandangan pragmatis-progresivisme, berpikir bukan sekedar merenungkan problem-problem abstrak yang melangit di mana sang pemikir berdiri di atas menara gading, atau duduk-duduk di balik meja. Dalam pandangan progresivisme, berpikir berarti berusaha mengubah dunia, berupaya memecahkan problem-problem empirik kehidupan di muka bumi.

Berangkat dari tesis pragmatisme Kyai Dahlan inilah peneliti terusik untuk menjajagi dan mengeksplorasi lebih jauh apakah pragmatismenya itu juga terejawantah dalam praksis pendidikan yang diselenggarakan dan diperjuangkannya. Sebagaimana dijelaskan di atas, dalam tradisi filsafat BaratAmerika Serikat aliran filsafat pragmatisme kemudian melahirkan progresivisme pendidikan yang melekat pada diri John Dewey. Dari pembahasan lika-liku perjuangan Kyai Dahlan dalam merintis pendidikan berkemajuan menunjukkan bahwa hasil penelitian ini semakin memperkuat tesis bahwa Kyai Dahlan benar-benar seorang manusia pragmatis, manusia amal yang berorientasi pada tindakan, dan hal itu terlihat dari butir-butir pemikiran dan praksis pendidikannya.

Tabel 3. Konstruksi Teori Pendidikan Berkemajuan

\begin{tabular}{lllll}
\hline \multicolumn{1}{c}{ Tujuan } & \multicolumn{1}{c}{ Kurikulum } & \multicolumn{1}{c}{ Subjek Didik } & \multicolumn{1}{c}{ Pendidik } & \multicolumn{1}{c}{ Metode } \\
\hline Menjadi manusia & Ilmu dan & Pelaku sosial & Menstimulasi akal & Dialog, problem \\
religius yang secara & teknologi & aktif, kapasitas & suci /kecerdasan & $\begin{array}{l}\text { solving \& metode } \\
\text { projek melalui }\end{array}$ \\
individul kecerdasan & modern plus & akal/ & subjek didik agar & pengalaman aktual \\
tumbuh (growth) & agama Islam. & kecerdasannya & tumbuh optimal & pengalan \\
optimal dan secara & & mampu & dan mampu & kehidupan. \\
sosial bersedia terlibat & & memahami dan & menjadi teladan & \\
dalam memajukan & & memecahkan & bagi subjek didik. & \\
(progress) kehidupan & & permasalahan & & \\
masyarakat. & & kehidupan. & & \\
\hline
\end{tabular}

Sumber: Dikembangkan dari Wirjosukarta, 1962, p. 67. 
Kembali ke dimensi pemikiran pendidikan Kyai Dahlan. Tinjauan dan analisis terhadap kunci-kunci pemikiran pendidikan Kyai Dahlan menemukan tiga konsep kunci, yaitu: akal (intelligence) atau kecerdasan sebagai piranti manusia memecahkan masalah-masalah kehidupan sosial, pengamalan (experience) merupakan interaksi individu dengan lingkungan, dan kehidupan sosial yang berkemajuan (progress). Ketiga konsep kunci itu, sebagaimana tampak pada tanda kurung di belakang masing-masing konsep, memiliki titik-titik kesepadanan yang saling beririsan dengan tiga dimensi pendidikan progresif John Dewey. Kyai Dahlan meyakini bahwa manusia dengan kemampuan akalnya dapat memecahkan masalah-masalah yang dihadapi dalam kehidupan di dunia ini. Pertumbuhan kapasitas akal manusia dimungkinkan karena terjadinya proses interaksi terus menerus dengan lingkungan. Interaksi manusia dengan lingkungan menghasilkan pengalaman. Proses interaksi terus-menerus antara manusia dengan lingkungannya ini secara individual akan menumbuhkan kecerdasan akal melalui proses rekonstruksi pengalaman secara berkelanjutan. Sedangkan secara sosial proses interaksi sosial mendorong dan membawa dampak pada kemajuan kehidupan sosial-empirik. Sementara itu, kehidupan itu sendiri bersifat dinamis dan selalu berubah serta penuh ketidakpastian, sehingga selalu memunculkan masalah-masalah baru yang menunggu untuk dipecahkan oleh manusia dengan cara-cara yang baru pula.

Berpangkal tolak dari sudut pandang kunci-kunci pokok pemikirannya, tidaklah berlebihan bila disebut bahwa pemikiran dan praksis pendidikan Kyai Dahlan berdampingan dalam satu mazhab dengan John Dewey, yaitu berada pada mazhab pendidikan progresif. Namun demikian, agar proses identifikasi pemikiran pendidikan lebih utuh mestinya tidak berhenti pada telaah atas konsep-konsep kunci yang digunakan, tetapi juga harus melibatkan sudut pandang yang lain. Dari sudut pandang lain, dalam hal ini sudut-sudut filsafat pendidikan dan teori pendidikan, ternyata ditemukan garis persilangan yang membelah progresivisme menjadi dua haluan. Fondasi pendidikan berkemajuan Kyai Dahlan adalah agama dan kehidupan sosial, sehingga lebih tepat diidentifikasi sebagai pendidikan progresif religius, sedangkan progresivisme pendidikan John Dewey berlandaskan pada filsafat empirik sekuler dan pengalaman kehidupan (kehidupan sosial), sehingga bisa disebut sebagai pendidikan progresif sekuler.

Dilihat dari sudut filsafat pendidikan yang peneropongannya meliputi tiga aspek, yaitu: ontologi, epistemologi dan aksiologi, garis persilangan kedua percabangan itu sudah mulai terlihat. Meskipun secara ontologis (realitas) keduanya meletakkan pengalaman empirik, yang merupakan produk dari interaksi individu dan lingkungannya sebagai suatu realitas. Namun dalam pandangan Kyai Dahlan pengalaman empirik bukan satusatunya kebenaran, karena masih ditambah wahyu dan akal sebagai suatu realitas. Karena mengakui kebenaran wahyu, maka ontologi/metafisika Kyai Dahlan disebut dengan metafisika pengalaman empirik-religius.

Nuansa perbedaan ontologis ini kemudian meluas dan merambah pada aspek epistemologis dan aksiologisnya. John Dewey meletakkan pengalaman empirik sebagai satusatunya jalan mencapai kebenaran, sementara Kyai Dahlan mengakui tiga sumber pengetahuan; pengalaman empirik, akal dan wahyu. Secara aksiologis, Kyai Dahlan memandang kebaikan (nilai baik-buruk) bersifat relatif untuk hal-hal yang merupakan produk dari pengalaman dan olah pikir manusia, termasuk pemahaman manusia atas wahyu. Tetapi untuk kebenaran wahyu (al-Quran) bersifat mutlak. Sementara itu, nilai baik-buruk menurut John Dewey selalu bersifat relatif dan situasional. Demikianlah, dari sudut filsafat pendidikan, titik-titik kesepadanan maupun garis yang membelah mazhab progresif ke dalam dua percabangan sudah terlihat semakin jelas: progresif sekular di satu sisi, dan progresif religius di sisi yang lainnya.

Titik-titik kesepadanan maupun garisgaris yang membelahannya semakin terlihat apabila memasuki perbincangan teori pendidikan. Untuk membedah teori pendidikan digunakan sistematika berikut: tujuan, kurikulum, subjek didik, pendidik, dan metode pembelajaran. Tujuan pendidikan menurut John Dewey maupun Kyai Dahlan mengasah dan membangkitkan kecerdasan (akal atau inteligen) sehingga seluruh potensi kepribadian (individu) seseorang dapat tumbuh (growth) dalam interaksi dan keterlibatannya dengan lingkungan. Interaksi dan keterlibatan sosial seseorang yang cerdas (inteligen/berVolume 4, Nomor 1, Juni 2016 
akal) pada urutannya dapat mendorong dan menggerakkan kemajuan sosial (progress). Hanya saja, perlu digarisbawahi bahwa metafisika Kyai Dahlan juga mencakup kebenaran agama (wahyu), sehingga konsep individu yang dimaksudkannya adalah manusia (individu) religius yang meyakini adanya kehidupan atau alam akhirat setelah kehidupan empirik-duniawiyah. Bagi manusia religius, tujuannya bukan hanya kebaikan di dunia ini, tetapi juga kebaikan kehidupan akhirat (surga).

Berdasarkan alur uraian di atas dapat disimpulkan bahwa fondasi pemikiran pendidikan berkemajuan berpijak pada agama dan kehidupan sosial yang bergerak secara interaktif-dialektis. Di atas fondasi itu tegak berdiri dimensi akal (kecerdasan/inteligen) yang memiliki fungsi sentral untuk memahami pesan-pesan agama di satu sisi, dan memahami anatomi masalah kehidupan sosial di sisi lain secara dinamis-kreatif dan dialektis. Dengan kemampuan akalnya, manusia bukan hanya mampu memahami, tetapi juga berusaha memecahkan permasalahan kehidupan sosial. Karena begitu strategisnya fungsi akal bagi manusia, maka Kyai Dahlan menandaskan bahwa setinggi-tingginya pendidikan adalah pendidikan akal, yang untuk mengasahnya diperlukan pengajaran ilmu mantik (logika). Penandasan ini menunjukkan bahwa Kyai Dahlan sangat menghargai akal (kecerdasan/inteligen), sehingga pendidikan harus mampu mendorong dan merangsang pertumbuhan (growth) akal (kecerdasan) secara terus-menerus melalui interaksi sosial yang menantang. Keterlibatan dan pergumulan manusia yang telah terasah akalnya (inteligen) dalam kehidupan sosial mampu menggerakkan kemajuan sosial (progress)

Bila bagan konseptual pendidikan berkemajuan Kyai Dahlan diilustrasikan seperti bangunan rumah, maka atapnya adalah tujuan pendidikan. Sebagaimana dijelaskan di atas, tujuan pendidikan menurut Kyai Dahlan adalah mengasah dan membangkitkan kecerdasan (akal atau inteligen) sebagai pembuka seluruh potensi kepribadian (individu) dapat tumbuh (growth) optimal melalui interaksi dan keterlibatannya dengan lingkungan. Pada saat bersamaan keterlibatan dan interaksi sosial itu juga menggerakkan kemajuan sosial (progress). Tujuan pendidik progresif John Dewey hanya sampai di sini (pengalaman empirik-duniawi), sedangkan Kyai Dahlan melampauinya, karena juga meliputi kebaikan kehidupan akhirat (surga).

Dari paparan reflektif di atas dapat disimpulkan bahwa pragmatisme K.H. Ahmad Dahlan juga termanifestasi dalam praksis pendidikan. Kyai Dahlan menempatkan pendidikan sebagai wahana tajdid dan dakwah. Pendidikan berkemajuan dapat dipahami sebagai praksis pendidikan progresif religius yang tidak hanya mendorong kemajuan kehidupan empirik duniawi, tapi juga kemuliaan kehidupan eskatologis-ukhrowiyah. Pendidikan berkemajuan berlandaskan agama dan kehidupan sosial yang sangat menghargai kecerdasan (akal/inteligen) sebagai piranti untuk memahami pesan-pesan agama dan anatomi kehidupan sosial, dan bertujuan untuk menumbuhkan akal (kecerdasan) sehingga seluruh kepribadiannya bertumbuh (growth) dan menggerakkan kemajuan sosial (progress).

\section{SIMPULAN DAN SARAN}

\section{Simpulan}

Berdasarkan pembahasan di atas dapat disimpulkan bahwa: (a) fondasi pendidikan berkemajuan adalah agama yang berinteraksi secara dialektis dengan problematika kehidupan sosial; (b) ditemukan tiga dimensi pendidikan berkemajuan, yaitu akal (kecerdasan/inteligen), pengamalan (pengalaman), dan berkemajuan (progress), di mana ketiga dimensi tersebut sebangun dengan dimensi pendidikan progresif John Dewey; (c) filsafat dan teori pendidikan K.H. Ahmad Dahlan bercorak progresif religius; dan (d) pendidikan berkemajuan berlandaskan agama dan kehidupan sosial yang sangat menghargai kecerdasan (akal/inteligen) sebagai piranti untuk memahami pesan-pesan agama dan anatomi kehidupan sosial, dan bertujuan untuk menumbuhkan akal (kecerdasan) sehingga seluruh kepribadiannya bertumbuh (growth) dan menggerakkan kemajuan sosial (progress).

\section{Saran}

Dari simpulan di atas, saran berikut perlu dipertimbangkan, bahwa arah inovasi pendidikan dikembangkan pada tiga dimensi, yaitu menghargai akal/kecerdasan, berlandaskan moralitas agama, dan mendorong kerja sama dan kepedulian sosial 


\section{DAFTAR PUSTAKA}

Alfian. (1989). Muhammadiyah: The political behavior of a Muslim modernist organization under Dutch colonialism. Yogyakarta: UGM Press

Alfian, T. I (1992). Tentang metodologi sejarah. Dalam Ibrahim Alfian, T et.al (Eds.). Dari babad dan hikayat sampai sejarah kritis. Yogyakarta: UGM Press.

Akinpelu, J.A. (1988). An introduction to philosophy of education. London \& Basingstoke: Macmillan

Arifin, M.T. (1987). Gagasan pembaharuan Muhammadiyah dalam pendidikan. Jakarta: Pustaka Jaya.

Barnadib, I. (1982). Arti dan metode sejarah pendidikan. Yogyakarta: Yayasan Penerbitan FIP-IKIP Yogyakarta.

Barnadib, I. (2002). Filsafat pendidikan. Yogyakarta: Adi Cita.

Brameld, T. (1955). Philosophies of education in cultural perspective. New York: Holt, Rinehart \& Winston.

Brubacher, J.S. (1978). Modern philosophies of education. New York: McGrawHill Book Company.

Basral, A.N. (2010). Sang pencerah. Bandung: Mizan.

Dahlan, K.H. A. (1923). Tali pengikat hidup manusia. Dokumentasi Suara Muhammadiyah.

Dahlan, K.H.A. (1922). Peringatan bagi sekalian Muslimin (Muhammadiyah). Dokumentasi Suara Muhammadiyah.

Dahlan, K.H.A. (1915). Agama Islam. Dalam Suara Muhammadiyah No.2/Th I.

Dahlan, K.H.A. (1935). Faqih tjekakan. (Kadjawekaken saking kitab Fathoe'l Qorib). Surakarta: Moehammadijah Bg Taman Poestaka Soerakarta.

Dewey, J. (1997). Experience \& education. New York: Simon \& Schuster.

Dewey, J. (2001). Democracy and education. Pennsylvania: The Pennsylvania State University.
Dewey, J. (1920). Reconstruction in philosophy. New York: Henry Holt \& Company.

Fadjar, A. M. (2010). Paradigma Pendidikan Muhammadiyah. Dalam Suyatno et.al. (ed.). Revitalisasi pendidikan Muhammadiyah di tengah persaingan nasional dan global. Jakarta: Uhamka Press.

Fakhrudin, A .R. (2015). Tak lelah membimbing umat. Yogyakarta: SM.

Gottschalk, L. (2009). Mengerti sejarah. Terjemahan Nugroho Notosusanto. Jakarta: UI-Press.

Gutek, G.L. (1974). Philosophical alternatives in education. Columbus: A Bell \& Howell Company.

Hadjid, KRH. (2008). Pelajaran K.H.A. Dahlan: 7 falsafah ajaran dan 17 kelompok ayat Al-Qur'an. Yogyakarta: LPI PP Muhammadiyah.

Kahin, G.M.T. (1995). Nasionalise dan revolusi kemerdekaan Indonesia. Surakarta: UNS Press.

Kenji, T. (Maret 1986). Kartini's image of Java's landscape. East Asian Cultural Studies. Vol. XXV, pp. 1-4.

Kneller, G.F. (1971). Introduction to the philosophy of education. New York: John Wiley \& Sons, Inc.

Knight, G.R. (1982). Issues and alternatives in educational philosophy. Michigan: Andrews University Press.

Kuntowijoyo. (2003). Metodologi sejarah. Yogyakarta: Tiara Wacana.

Kuntowijoyo. (1998). Pengantar. Dalam Shihab, Alwi. Membendung arus: Respon gerakan Muhammadiyah terhadap penetrasi misi Kristen di Indonesia. Bandung: Mizan.

Kuntoro, S, A. (1985). Dimensi manusia dalam pemikiran pendidikan. Yogyakarta: Nur Cahaya.

Kuntoro, S.A. (2006). Menelusuri perkembangan pendidikan nasional Indonesia: Peran pendidikan bagi integrasi bangsa. Dalam Sismono La Ode \& Rodhi As'ad. (Ed.). Kearifan Volume 4, Nomor 1, Juni 2016 
sang professor, bersuku-suku untuk saling mengenal. Yogyakarta: UNY Press.

Kuntoro, S.A. (2015). Revitalisasi sistem pendidikan Muhammadiyah menghadapi MEA: pokok-pokok pembahasan, Makalah disampaikan dalam FGD Revitalisasi sistem pendidikan Muhammadiyah menghadapi MEA yang diselenggarakan Majelis Dikti PP Muhammadiyah, tanggal 27 Juni 2015 di UMY

Lubis, A. (1993). Pemikiran Muhammadiyah dan Muhammad Anduh. Jakarta: Bulan Bintang.

Maarif, A. S. (1996). Islam dan masalah kenegaraan. Jakarta: LP3ES.

Majelis Pengajaran Muhammadiyah. (1924). Leerplan sekolah Muhammadiyah 1922. Suara Muhammadiyah No. 4.

Noer, D. (1994). Gerakan modern Islam di Indonesia 1900-1942. Jakarta: LP3ES.

Ornstein, A.C. \& Levine, D.U. (1989). Foundations of education. Boston: Houghton Mifflin Company.
Poerbakawatja, S.(1970). Pendidikan dalam alam Indonesia merdeka. Jakarta: Gunung Agung.

Steenbrink, K.A. (1994). Pesantren madrasah sekolah. Jakarta: LP3ES.

Tafsir, A. (1987). Konsep pendidikan formal dalam Muhammadiyah. Disertasi, tidak dipublikasikan. IAIN Syarif Hidayatullah Jakarta.

Van Peursen, C.A. (1980). Orientasi di alam filsafat. (Terjemahan Dick Hartoko). Jakarta: Gramedia.

Wirjosukarto, A.H.. (1962). Pembaharuan pendidikan \& pengajaran Islam jang diselenggarakan oleh pergerakan Muhammadijah. Yogyakarta: Penjelenggara Publicasi Pembaharuan Pendidikan/ Pengadjaran Islam.

Zamroni. (2010). Pendidikan Muhammadiyah pada abad ke-21. Dalam Suyatno et. al. (Eds). Revitalisasi pendidikan Muhammadiyah di tengah persaingan nasional dan global. Jakarta: Uhamka Press. 